\title{
4. Sorcery and Witchcraft as a Negative Force on Economic and Social Development in Solomon Islands
}

\author{
Lawrence Foana'ota
}

\section{Introduction}

The main focus of this chapter is on sorcery and witchcraft as a negative force on economic and social development in Solomon Islands. Throughout Solomon Islands, many people believe in different types of sorcery and witchcraft. For example, in the Marovo Lagoon, Western Province, the type of sorcery and witchcraft practised there is called pela; on Guadalcanal it is called vele; while in North Malaita it is called arua. These are just a few of the practices that still exist in these islands. This discussion will focus on these examples in order to understand their negative effects.

It is expected that by discussing these examples, some understanding can be achieved of the consequences of these beliefs today on the economy, society, and law and order in the islands. The information will also cover the way allegations of sorcery and witchcraft are dealt with at the community level.

The discussion will conclude by providing some concrete policy recommendations for the way forward in dealing with this practice that is causing much anger, fear, frustration and hindrance to the economic and social development in contemporary Solomon Islands society.

The information contained in this chapter was collected by me during informal conversations with people from the northern part of Malaita Island, my original home, and also from other language groups in the islands. Other sources of information came from newspapers, books and personal knowledge as well as experiences during field trips to other parts of the country while I was director of the Solomon Islands National Museum from 1972 until recently.

Like other countries in Melanesia - in particular Papua New Guinea, Fiji, New Caledonia and Vanuatu — the Solomon Islands population of more than 500,000 
consists of people with a diverse and rich cultural and linguistic heritage. Within this cultural diversity and richness, there are good and bad practices which some people still maintain and apply widely in some communities today.

A common and widely known example of a bad cultural practice in Melanesian countries today is sorcery and witchcraft, including related killings. Generally, the forms of sorcery and witchcraft as a negative force, and any related killings, vary from country to country and island to island in Melanesia. This also applies to the views and reactions of the people including authorities in the communities, churches and governments in this region.

In the past, death or suffering and mishaps believed or suspected to be caused by sorcery and witchcraft were sometimes followed by the killing of the practitioner to prevent further similar incidents occurring. Today, cases of actual killings are rare, but other means of dealing with deaths or events suspected to relate to these practices do exist - for example, destruction of personal property, compensation demands and chasing away suspected persons.

In the northern part of Malaita Province, arua is the most commonly practised and feared kind of sorcery and witchcraft. In the past, if someone was believed to have caused the death of another person with the use of arua, that person must be killed either by the victim's relatives or a hired killer from another tribe. The hired killer would normally be paid with traditional shell money strings known as tafuliae. One shell money consists of 10 strings with lengths varying from 6 to 12 feet (Figure 1). In this part of Solomon Islands, the general belief is that 'all deaths are supposed to be caused by sorcery, [and] since a woman is often not related by blood ties to her husband's kinsmen, wives would frequently be suspected' (Hogbin 1939:53).

My great-grandmother, Thangotafia, was a victim of such sorcery- and witchcraft-related killing carried out in 1910 at Funoa, in Toabaita, North Malaita, by a hired killer from another tribe. He was paid for carrying out the mission with one of the 10 strings of shell money similar to those shown in Figure 1. She was killed by mistake while the real sorcerer or witch escaped unscathed. The instruction given to the hired killer was to go to Funoa hamlet where the suspected sorcerer was staying and look for a woman weaving a basket and not the one carrying a baby. Unfortunately, when he arrived at the scene it was my great-grandmother who was weaving, while the suspect was carrying my great-grandmother's baby. Thangotafia was shot with a rifle. This killing was carried out in retaliation for the death of a person in a neighbouring tribe. The death was believed to have been caused by sorcery and witchcraft known as arua. The relatives believed that the witch took remains of the deceased's food and fed it to the arua, which was in the form of a snake. 
4. Sorcery and Witchcraft as a Negative Force on Economic and Social Development in Solomon Islands

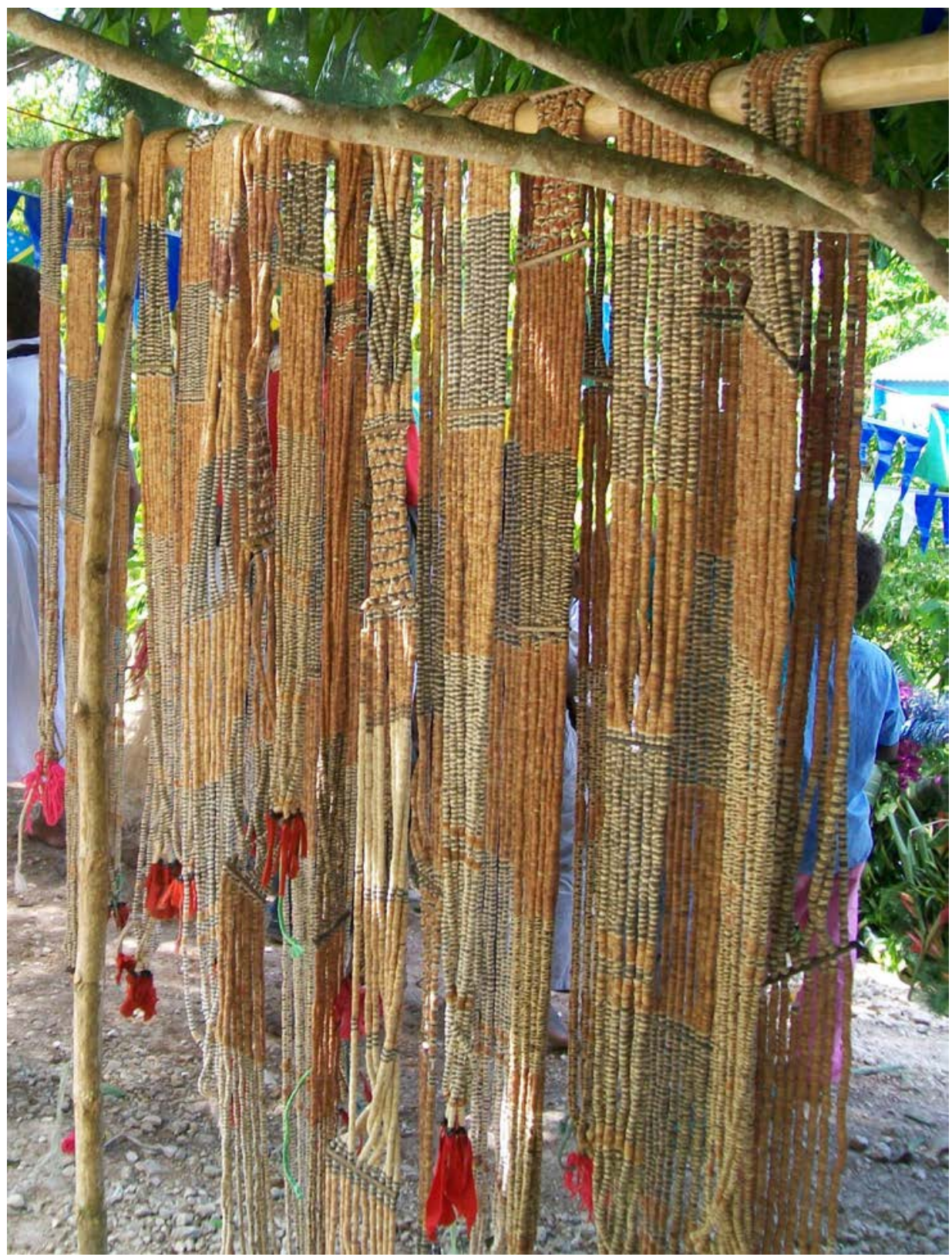

Figure 1: Shell money strings used as traditional currency.

Source: Photograph by Lawrence Foana'ota. 
In 1967 at King George VI Secondary School, Honiara, the only government secondary school at that time, an incident happened that was believed to have been caused by witchcraft known as vele from Guadalcanal. This particular incident involved one of the students from Guadalcanal who went into the forest with others collecting bush materials for a new chapel building at the school. His recollection of what actually happened was that he met a vele man who used his magic to make him lose his sense of direction and wander away from his group, deeper into the forest. Since he knew how to cure the effects of this particular witchcraft, he was able to treat himself and regain his senses. It was already dark so he had to find his way back to the school. The school authority was alerted of the missing student and a search was mounted to find him. He finally arrived at the school past midnight, tired and worn out. ${ }^{1}$

Those who practice vele on Guadalcanal use it either to kill another person or for the user's own benefit. For example, in 2004 a woman from a community in the mountains near Marau on Guadalcanal had an encounter with a vele man while she was working in her garden. After he had applied all the necessary procedures, which included making her lose her memory so that she could not remember him, he told her that she had only a few days to live then allowed her to return to her family in the community. Fortunately, she recovered after a group of young men from a church visiting the area from Honiara prayed for her. ${ }^{2}$

During the ethnic tension from 1999 to 2003, several incidents occurred, especially in Honiara. One of these incidents happened in a church-administered college where boys and girls board at the school. According to information from some of the students, six of the boys entered one of the girls' dormitories at night and shaved off hair from the girls' private parts without the girls knowing what was happening until they woke up the next morning. These boys used pela, which is a type of witchcraft practice from Marovo, Western Province, to turn into rats and flying foxes before they entered the dormitories. When those who were involved became known to the church and school authorities they were immediately expelled. ${ }^{3}$ Pela is also believed to be used by someone practising it to eat vital organs such as the heart or liver by simply looking with piercing eyes at someone's chest.

At the height of the conflict in 2001, my house was broken into at night. This was a scary incident because the intruder(s) used witchcraft to enter through a tiny window before entering the main bedroom. The door and windows of the main bedroom were securely locked, yet the intruder(s) managed to enter.

\footnotetext{
Witnessed by the author, who was also a student at the school. Information provided by the members of the church group.

Students' own story about the incident. Church authorities were reluctant to speak about this incident.
} 
This incident happened without my family being aware until the next morning when they woke up and realised the doors and windows were unlocked and some personal belongings were missing.

The family found some objects the intruder(s) used to enter the master bedroom. On an ironing board near the windows, they found lime and a midrib from a coconut leaf. When information about the incident was heard by some of the neighbours, they immediately said the intruder(s) may have used either pela or vele witchcraft practices from Western or Guadalcanal provinces. ${ }^{4}$ Their conclusion was based on the fact that these two types of practices usually cause victims to fall into deep sleep when someone wants to steal or to do stupid things, such as the incident in the church college.

In an incident in 2012 a woman almost killed her husband and one of his relatives. One night the husband wanted to sleep with his wife and suddenly she pushed him flying into the air and he landed against the wall of their house. Before he fell unconscious he saw a rat entering his wife through her private parts. When he regained consciousness his wife told him she had received the arua from another woman and it was impossible to get rid of it from her body. The husband called the chiefs to investigate the wife's involvement in this practice. After the chiefs confirmed that she had the arua, the husband told her to go back to her family. Early this year two brothers and their families were sent from their homes due to suspicion of practising arua and have gone back to their father's original home in another part of Malaita. ${ }^{5}$

Anyone who practises any of these forms of sorcery and witchcraft is regarded as an outcast or a bad person; hated, feared and despised by members of their own families or other communities. Recently, reports have been received that some families' lives have been threatened, while others have been asked to leave or have been chased out of their homes and have gone to settle in other places or on other islands.

In some other cases, suspects' homes have been destroyed (Di'isango 2014; Figure 2) while others have paid compensation since they do not have anywhere else to migrate to and so they have been allowed to stay, but under close monitoring. These kinds of harsh reactions are directed mainly towards those practising arua and less towards those who practice either pela or vele.

4 Personal encounter and experience.

5 Wesley Foarorongo, personal communication 2013 and February 2014. 




Figure 2: Home razed over sorcery claims.

Source: Photograph by Stephen Di'isango, Solomon Star, 6 August 2014.

Sometimes the practitioners are not welcomed into communities, especially when they have jealous minds, which may lead to killing someone who has a good permanent house, owns a business, has acquired a good education or has a major development project on his or her land. Their actions cause fear and division and affect relationships among members of families, communities and tribes.

The sudden deaths of politicians - recently, the member of parliament for Ngela Constituency - and deaths at different times of three brothers from the same family who had built permanent high-storey houses in Honiara between 2010 and 2013, as well as the death in 2013 of Delight Inomae's husband, who was a prominent SIBC radio announcer, ${ }^{6}$ were the results of sorcery and witchcraft, according to relatives and family members' beliefs.

Delays in the implementation of a number of important projects have been attributed to the effects of sorcery and witchcraft. For instance, the Bina Harbour Development Project that was initiated 30 years ago in 1984, the Suava

6 Inomae Delight, personal communication, April 2013. 
Bay Fisheries Project, and the Kadabina Industrial Park Project in which the government and landowners carried out the groundbreaking ceremonies in 2011-2012, are still to be developed before they can start operating.

Malaita Company, which was started in the late 1960s, operated a bus service along the north road of Malaita, and the Malaita Development Authority, which started in the 1980s, provided shipping services to different parts of the country using three passenger boats. Unfortunately, both companies have gone bankrupt.

People strongly believe that the delays and failures relating to these development projects and companies are caused by the effects of sorcery and witchcraft as a negative force.

During the colonial administration, 'charges of sorcery [were] officially ignored and around the early 1930s, a regulation on this subject was contemplated by the government but when the district officers furnished reports so many practical difficulties were raised that the matter was dropped' (Hogbin 1939:151).

This attitude continued until recently when a handful of government officials and a few individuals started talking about sorcery and witchcraft with members of the community.

Unlike Papua New Guinea, where discussion regarding sorcery and witchcraft is very strong at all levels, Solomon Islands seems to take a moderate approach to this issue. For example, in Papua New Guinea, the churches are very vocal about the need for a sorcery law. This is because the '[c]hurches in the country fear there will be more deaths in sorcery-related crimes if the government does not pass a sorcery act soon' (Solomon Star 2013a).

At the political level, the governor of Eastern Highlands Province, Papua New Guinea, was reported to say that repealing the country's Sorcery Act 1971 is 'unlikely to stop gruesome sorcery-related killings' (Solomon Star 2013b). The first sorcery-related killing to reach a national court, in 2013, involved a 21-yearold who was sent to prison for 30 years after he was found guilty of killing his aunt for sorcery (Solomon Star 2013c).

In Solomon Islands the politicians and churches do not speak out against sorcery and witchcraft and the courts have not charged anyone for any antisocial behaviour such as fist fighting, chasing families from their homes or destroying properties. No cases have been brought before the courts even though people believe that some sudden deaths or other unnatural incidents in their communities are related to the effects of sorcery and witchcraft. ${ }^{7}$

7 Moses Manata; data on a fist fight between a suspect and relatives of a deceased, which happened in Auki, the capital of Malaita Province, on 14 May 2013. Police did not take any action against those involved. 
The general belief in Solomon Islands is that the influence of Christianity has contributed positively to a reduction in the number of these cases and related killings in some places, while in others they have completely stopped. For instance, only the killings in retaliation to deaths were stopped, while the actual practices of witchcraft and sorcery continue, even though many Christian churches strongly condemn and oppose them. This seems to be the case in general throughout the communities in the islands.

Even though the majority of people are Christians, the present trend is that the number of those using negative forces and the deaths suspected to have been caused or associated with them has increased recently. In some instances, a number of those who claim to be Christians are also practising sorcery and witchcraft. Many of the practitioners are women but the number of men is also increasing. ${ }^{8}$

Today for instance, there are women and men who believe in God as well as in the power of using sorcery and witchcraft in meeting either their own or other family members' needs in any difficult situation. For example, if a family member is sick or a business is not gaining any profits, the first thing to do is pray for healing or revelation of the person or whatever forces may be causing the problems. When nothing happens, a priest, sorcerer or witch may be called upon to find out the causes or treat the effects with traditional or kastom medicine or offer a prayer. In return they will be paid or be given an offering, therefore benefiting economically from any services they provide.

\section{Conclusion}

In concluding these discussions, it is clear that sorcery and witchcraft is a negative force on economic and social development in parts of Solomon Islands contemporary society. Many Solomon Islanders believe that sorcery and witchcraft does exist and is rapidly increasing in the numbers of both mature and young people practising it.

All deaths and diseases are considered unnatural, so sorcery or witchcraft is always given as the main cause. Many people still believe that it exists and that practitioners always keep their practice secrets to themselves. If a sorcerer or witch has enemies he or she wishes to kill or make suffer, he or she would steal some of the victim's food remains or other items that may be associated with them, call up a creature from the spirit world with a spell and give it the fragments to eat. Anyone suspected of practising witchcraft will never admit this openly.

8 Information collected by the author between 2013 and July 2014. 
When a death occurs, relatives of the deceased always ask the question, who was the dead person most unfriendly with when he or she was alive. If someone had argued with him or her recently, this person is almost certain to be blamed. If not, the relatives would consider someone who might be envious of the victim's wealth or social status in the community. It is clear that people believe in sorcery and witchcraft as the main cause of accidents, deaths, diseases and failures either in business undertakings or in work.

It is also clear that the kinds of actions victims of sorcery and witchcraft and their relatives usually take in responding to the negative effects it causes do not go to the extreme of killing a suspect, as in other parts of Melanesia. Even if someone is suspected, the kinds of actions taken against such a person usually involve the destruction of personal property and sometimes fist fighting, but not killing. There are confirmed cases of these kinds of actions taken as recently as January and early August 2014.

Among the Christian communities, the family members or relatives usually pray with the culprits and forgive them without giving anything in return for the loss of a life, although some still do not agree with the practice of forgiveness.

The government's view is that it is not a murder case if someone is suspected to have died from sorcery and witchcraft. This view may be influenced by the fact that it is hard to come up with admissible evidence in a court of law and so it is impossible to convict anyone suspected. As a result, the government and church authorities have not paid much serious attention to incidents that are related to sorcery and witchcraft as a negative force on the economy and social development in the country until now.

Since current information indicates the number of people practising sorcery and witchcraft and the cases of suspicious incidents are rapidly increasing across Solomon Islands, it is very important for the government to take serious note now and put in place legal mechanisms to address these practices.

In concluding these discussions, communities, organisations and government institutions at all levels in the country need to acknowledge that sorcery and witchcraft is a cultural phenomenon that needs to be dealt with according to the people's customs or traditional ways of dealing with it. This should include a nationwide education program that highlights the negative effects sorcery and witchcraft is causing on the economic and social development in the country.

Further research work should be carried out to document the diversity of practices and the best way to control or eliminate some of its negative impacts. Local authorities such as chiefs, elders, women and youth leaders are empowered 
by a legal system that would assist them if they knew that a person suspected could be legally imprisoned, and they might put themselves at risk in finding acceptable evidence.

Finally, the government should pass a law to address the superstitious beliefs that are having significant negative effects in the economic and social development of the country. Such law should have a provision whereby customary doctors who claim to be either fortune tellers or healers could be prosecuted. Any person who accuses others of practising sorcery and witchcraft should also be able to be punished under such a law in the future.

\section{References}

Di'isango, S. 2014. Home Razed over Sorcery Claims. Solomon Star, 6 August.

Hogbin, H.I. 1939. Experiments in Civilization: The Effects of European Culture on a Native Community of the Solomon Islands. London: Routledge and Kegan Paul.

Solomon Star 2013a. Churches: Sorcery Law Needed. Solomon Star Issue No. 5108, 5 March, p. 14.

Solomon Star 2013b. Governor on Sorcery. Solomon Star Issue No. 5150, 22 April, p. 14.

Solomon Star 2013c. Sorcery Killer Jailed for 30 Years in PNG. Solomon Star Issue No. 5152, 24 April, p. 14. 
This text is taken from Talking it Through: Responses to Sorcery and Witchcraft Beliefs and Practices in Melanesia, edited by Miranda Forsyth and Richard Eves, published 2015 by ANU Press, The Australian National University, Canberra, Australia. 